\title{
Phylogenetic Diversity of Ficus Species Using HAT-RAPD Markers as a Measure of Genomic Polymorphism
}

\author{
S. Anuntalabhochai ${ }^{1}$, W. Phromthep ${ }^{2}$, S. Sitthiphrom ${ }^{3}$, R. Chundet ${ }^{4}$ and R.W. Cutler ${ }^{*}, 5$ \\ ${ }^{I}$ Biology Department, Faculty of Science, Chiang Mai University, Chiang Mai 50200, Thailand \\ ${ }^{2}$ Department of Biology Faculty of Science and Technology, Sakon Nakhon Rajabhat University, Sakon Nakhon 47000, \\ Thailand \\ ${ }^{3}$ Department of Science, Faculty of Science and Technology, Loei Rajabhat University, Loei 42000, Thailand \\ ${ }^{4}$ Department of Biology, Faculty of Science, Maejo University, Chiang Mai 50200, Thailand \\ ${ }^{5}$ Bard College, Annandale New York, 12504, USA
}

\begin{abstract}
To create a molecular marker characterization for twenty species of Ficus, eight decamer primers were used to randomly amplify these species genomic DNA producing a total of 172 distinct polymorphic band patterns. One band was chosen to be converted into the more robust sequence characterized amplified region (SCAR) marker format to provide a unique molecular marker characterization for the variety of Ficus hirta. This technique for species identification and characterization provides a morphologically independent test to verify relatedness and provide species information particularly for cases where such identification was previously untenable such as in the case of morphologically indistinguishable plant cuttings.
\end{abstract}

Keywords: Ficus, genomics, HAT-RAPD, SCAR markers.

\section{INTRODUCTION}

Having been cultivated in the eastern Mediterranean zone since 4000 B.C., the fig tree (Ficus spp) has one of the longest histories as a fruit tree in human history [1]. Trees of the Ficus species belong to the family Moracea and can be easily distinguished by the presence of roots growing from the branches [2]. In modern times, fig cultivation has spread throughout the world and in warm temperate climates it constitutes an important cash crop. Fig trees produce an edible inflorescence known as a syconium (fig), which consists of a fleshy cup with a small orifice at one end enclosed by interlocking scales. Within the fig are hundreds of minute flowers which, after pollination usually by wasps, develop into tiny fruit. The fruit is consumed either fresh or preserved (dried or canned).

In addition to being eaten as a fruit, several studies have reported that some Ficus species possess medicinal properties. For example, the leaves of Ficus bengalensis have been found to reduce the symptoms of ulcers and the aerial roots have been used to treat gonorrhea [3], and F. carica and $F$. pentoniana contain flavonoid alkaloids which are known to have antioxidant properties [4-5]. Also, the roots of the variety $F$. hirta when boiled produce a gel which has been shown to be an effective antipyretic [6].

As a crop grown for both food consumption and a perceived medicinal value, understanding the relatedness of different species in the Ficus family could provide insight into the distribution and evolution of beneficial traits. To

*Address correspondence to this author at the Bard College, Annandale New York, 12504, USA; E-mail: cutler121@gmail.com date such characterizations have been done solely using phenotypic characters. As a complement to morphological, physiological and agronomic traits, all of which are purely phenotypic, genetic analyses using molecular markers can provide a phenotypically independent method for cultivar and clone characterization. Some of the difficulties with morphological traits include (i) a limited number and low heritability of phenotypic characters; (ii) difficulty in obtaining an accurate distinction between different cultivars before plants have attained the adult phase of life; (iii) an inability to distinguish cultivars from cuttings of in vitro cultured plants. To overcome these difficulties, a variety of methods have been used to fingerprint fig cultivars such as isozymes [7], randomly amplified polymorphic DNA (RAPD) [8-10]; simple sequence repeats [11], and AFLP [12]. Methods such as RAPD markers can save time and labor costs and only require a small amount of DNA as compared to other tools such as RFLP, which require additional steps such as restriction digestion, blotting, and hybridization [13].

To be able to characterize phylogenetic relationships between various fig species, a more discriminating molecular method is required which ideally would share the benefits of RAPD by being inexpensive and not labor intensive. One such method uses sequence characterized amplified region (SCAR) markers [14] to amplify unique regions in different varieties or species. Such a methodology has been successfully demonstrated in a characterization of the temperature dependence of lychee cultivars [15], longan cultivars [16], as well as in the cut flower Curcuma [17]. By extracting a single genetically defined loci, the presence or absence of an amplified band can be used as a distinguishing unique character of that species or clade of species. In addition this al- 
lows an immediate scoring of results by checking for the presence/absence of expected PCR band [18] which can eliminate the need for sequencing of the amplification product thereby decreasing the overall cost of the analysis.

Using HAT-RAPD markers as an initial screen we have characterized the relatedness of twenty Ficus spp and determined unique SCAR markers which can distinguish single lineages of this fruit tree. These characters were then used to generate a phylogram upon which morphological versus genomic characters are compared.

\section{MATERIALS AND METHODOLOGY}

The twenty Ficus spp used in this study were kindly provided by the Biology Department, Faculty of Science, Raschapat Skolnakorn University, Thailand. Young leaf pieces were used to isolate the total genomic DNA from each of these species using the cationic hexadecyl trimethyl ammonium bromide (CTAB) method of [19]. Using this genomic DNA, PCR amplification was performed using decamer primers (Operon Technologies) following the high annealing temperature rapid amplified polymorphic DNA (HAT-RAPD) protocol. Briefly, the PCR reaction used a total volume of $20 \mu \mathrm{l}$ containing, 10xPCR buffer (Tris- $\mathrm{HCl}$ $100 \mathrm{mM}, \mathrm{pH} 8.3, \mathrm{KCl} 500 \mathrm{mM}), 100 \mu \mathrm{M}$ each dNTP (Promega), $1.5 \mathrm{mM} \mathrm{MgCl}$ (QIAGEN), 0.5 unit of Taq DNA polymerase (QIAGEN), $10 \mathrm{ng}$ of DNA template, and $0.3 \mu \mathrm{M}$ 10-base primers (Operon Technologies) using eight decamer primers (Table 1). This $20 \mu \mathrm{l}$ solution was then amplified in a Perkin-Elemer thermal cycler (Gene Amp PCR system 2400) using the following cycling profile: $95^{\circ} \mathrm{C}$ for $2 \mathrm{~min}-$ utes, followed by 35 cycles of denaturing at $95^{\circ} \mathrm{C}$ for $30 \mathrm{sec}-$ onds, annealing at $46-55^{\circ} \mathrm{C}$ for 30 seconds, and extension at $72^{\circ} \mathrm{C}$ for 45 seconds, followed by a final 5 minutes at $72^{\circ} \mathrm{C}$. This cycling profile has been shown to increase band reproducibility due to the increased annealing temperature which limits imperfect template matches [20]. After the thermal cycling program had been completed, the amplification samples were stored at $4{ }^{\circ} \mathrm{C}$ prior to a standard agarose gel electrophoresis run.

Photographs from the ethidium bromide stained agarose gels were used to score the data for the HAT-RAPD analysis. Each DNA fragment amplified by a given primer was treated as a unit character where the fragments were scored as either present (1) or absent ( 0 ) for each of the primeraccession combinations. Only bands which were reproduced on three separate runs were considered in this analysis and the presence or absence of each band was scored in a binary data matrix.

Bands patterns corresponding to known phenotypic traits, for instance the medicinal properties claimed for the fig, were then compared against this data matrix to find band regions to be further examined phylogenetically and ultimately characterized using SCAR markers. A unique band approximately $400 \mathrm{bp}$ in length presenting in the $F$. hirta species was then purified using the QIAquick Gel Extraction kit (QIAGEN) and ligated into a GEM T-Easy vector (Promega) using the manufacturers recommended procedure. In order to check for specificity of the chosen region for SCAR marker production, this DNA fragment was labeled with DIG-High prime (Roche Applied Science) following the manufacturers recommended procedure then used as a probe to hybridize to HAT-RAPD markers of all Figus spp using the standard southern blot method. This fragment was then sequenced by the Bioservice Unit (Thailand) and SCAR primers were designed containing the original decamer RAPD primer sequence followed by between six to ten internal bases as described by Paran and Michelmore [14]. These SCAR primers were then synthesized by the Bioservice Unit (Thailand). Finally, ethidium bromide stained agarose gels were formed using the cultivar DNA amplified with these newly designed SCAR primers.

\section{RESULTS AND DISCUSSION}

Using a total of eight different decamer primers to randomly amplify genomic DNA from twenty Ficus species, a total of 172 distinct polymorphic band profiles were produced with fragments ranging in size from 200 to 2,500 base pairs as shown in Table 1. Representative HAT-RAPD patterns for the two primers (OPL05 and OPL17) are shown in Fig. (1).

\section{SCAR Marker Characterization}

As a proof of principle, one variety-specific HAT-RAPD marker was initially selected for transformation into the more robust SCAR marker. For the decamer primer OPX09, one band approximately $400 \mathrm{bp}$ in size which amplified for the variety $F$. hirta was initially chosen and then successfully cloned into the GEM-T Easy vector. All of the fragments sizes analyzed and checked by EcoRI digestion methods

Table 1. List of Primers and their Sequence Used in HAT-RAPD Analysis, Number of Fragments and the Fragment Size Range

\begin{tabular}{|l|c|c|c|c|}
\hline Primer Name & Sequence (5'--- 3') & Total Number of Amplified Fragment & Number of Polymorphic Fragment & Fragment Size Range (bp.) \\
\hline \hline 1. OPD08 & GTGTGCCCCA & 23 & 23 & $200-1,500$ \\
\hline 2. OPG13 & CTCTCCGCCA & 22 & 22 & $200-1,700$ \\
\hline 3. OPL05 & ACGCAGGCAC & 22 & 21 & $300-2,500$ \\
\hline 4. OPL17 & AGCCTGAGCC & 21 & 22 & $350-2,500$ \\
\hline 5. OPW06 & AGGCCCGATG & 22 & 23 & $300-2,000$ \\
\hline 6. OPX09 & GTGACCGAGT & 23 & 17 & $200-2,500$ \\
\hline 7. OPAM12 & TCTCACCGTC & 17 & 22 & $200-1,500$ \\
\hline 8. OPAS10 & CCCGTCTACC & $\mathbf{1 7 2}$ & $\mathbf{1 7 2}$ & $300-2,500$ \\
\hline & Total & & $\mathbf{2 0 0 - 2 , 5 0 0}$ \\
\hline
\end{tabular}



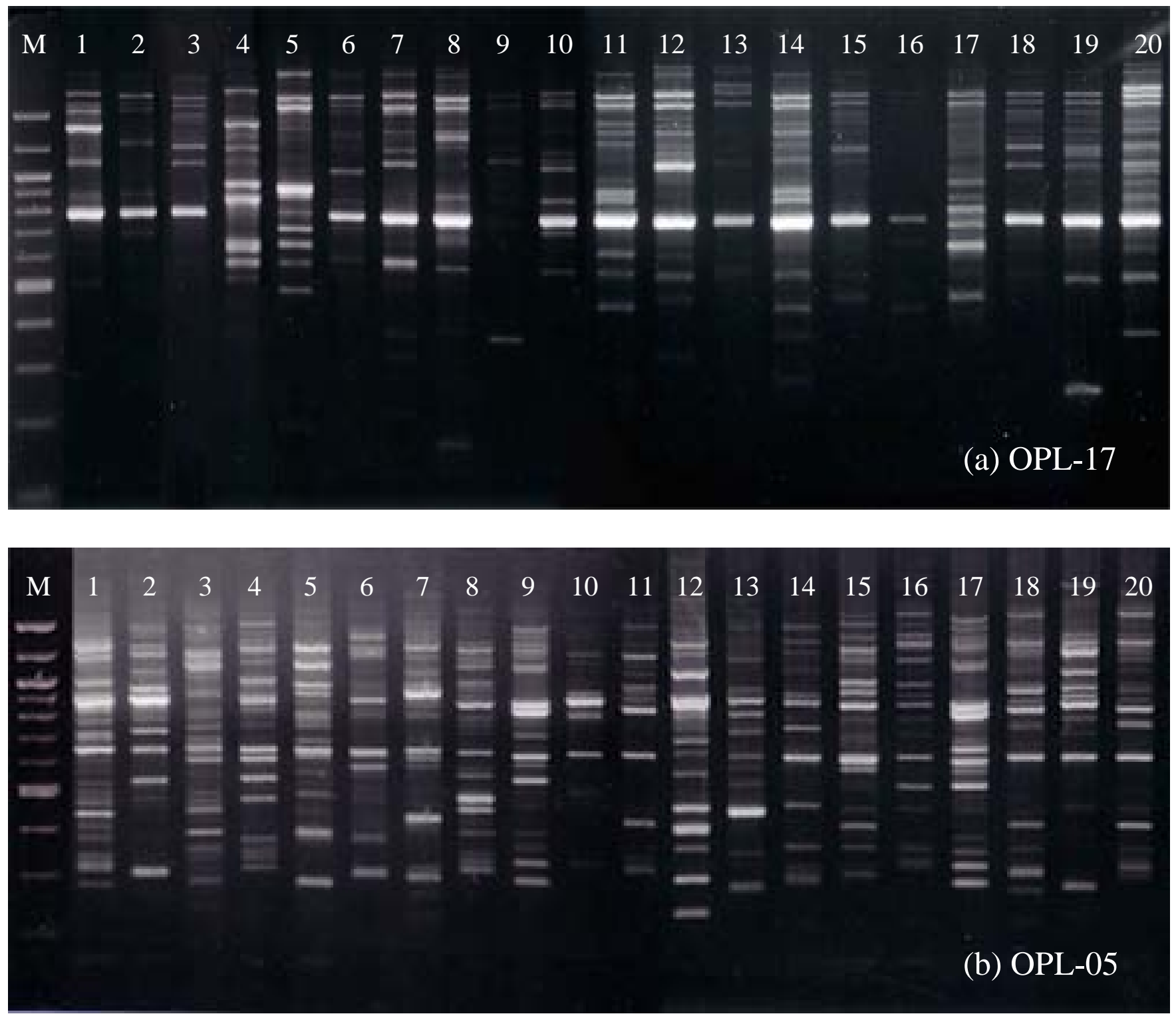

Fig. (1). Representative HAT-RAPD patterns for 20 Ficus species obtained by amplification with primers OPL17 (a) and OPL05 (b). The species listed by lane are: 1) $F$. microcarpa, 2) $F$. hispida, 3) $F$. variegata, 4) $F$. hirta, 5) $F$. religiosa, 6) $F$. fistulosa, 7) $F$. altissima, 8) $F$. tinctoria, 9) $F$. superba, 10) F. benjamina, 11) F. callosa, 12) F. sp, 13) F. racemosa, 14) $F$. sp., 15) $F$. sp., 16) $F$. sp., 17) $F$. lacor, 18) $F$. sp., 19) F. sp., 20) F. rumphii and the 100 bp DNA ladder marker designated with M.

were similar to the original HAT-RAPD marker in Fig. (2a).

One cloned marker, OPX09 was DIG-labeled for probe analysis and hybridized to the blotted HAT-RAPD gel. The hybridization signal corresponded to the expected HATRAPD band, indicating that the cloned marker (OPX09) was derived from the amplified HAT-RAPD product and therefore the initial HAT-RAPD band was not a false positive as shown in Fig. (2b). Therefore, this cloned marker (OPX09) was chosen to be converted to a SCAR marker. The cloned marker (OPX09) was sequenced using the SILVER SEQUENCE $^{\mathrm{TM}}$ DNA Sequencing System (Promeca). This sequence showed neither an open reading frame nor homology with other known coding sequences Table 2.

Using this sequence, two SCAR primers were developed where each primer contained the original 10-mer RAPD primer followed by the next nine internal bases of the amplified sequence. These SCAR primers are shown in Table 3. To test the specificity of this SCAR primer pair, the genomic DNA of the 20 Ficus species were amplified with the primer pair, and a single band of the same size as the progenitor RAPD fragment was amplified by SCAR primer pair, OPX09 $\mathrm{F}_{398} / \mathrm{OPX} 09 \mathrm{R}_{398}$ in only the chosen species $F$. hirta as shown in Fig. (2c).

\section{Morphological Trait Analysis}

The HAT-RAPD markers of the 172 loci were used to construct a similarity matrix and generate a dendogram based on cluster analysis using UPGMA method. This dendogram (Fig. 3) provided an additional check that the relatedness of the twenty Ficus species examine in study roughly upheld the known morphological relationships. The 20 Ficus 


\section{$\begin{array}{llllllllllllllllll}M & 1 & 2 & 3 & 4 & 5 & 6 & 7 & 8 & 9 & 10 & 11 & 1213141516 & 17181920\end{array}$}

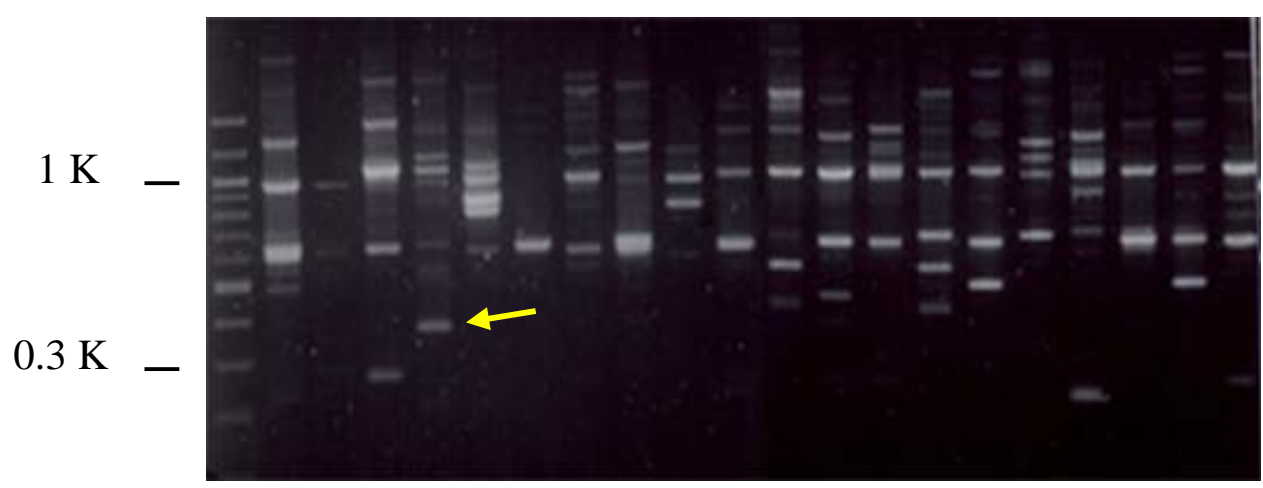

(a)

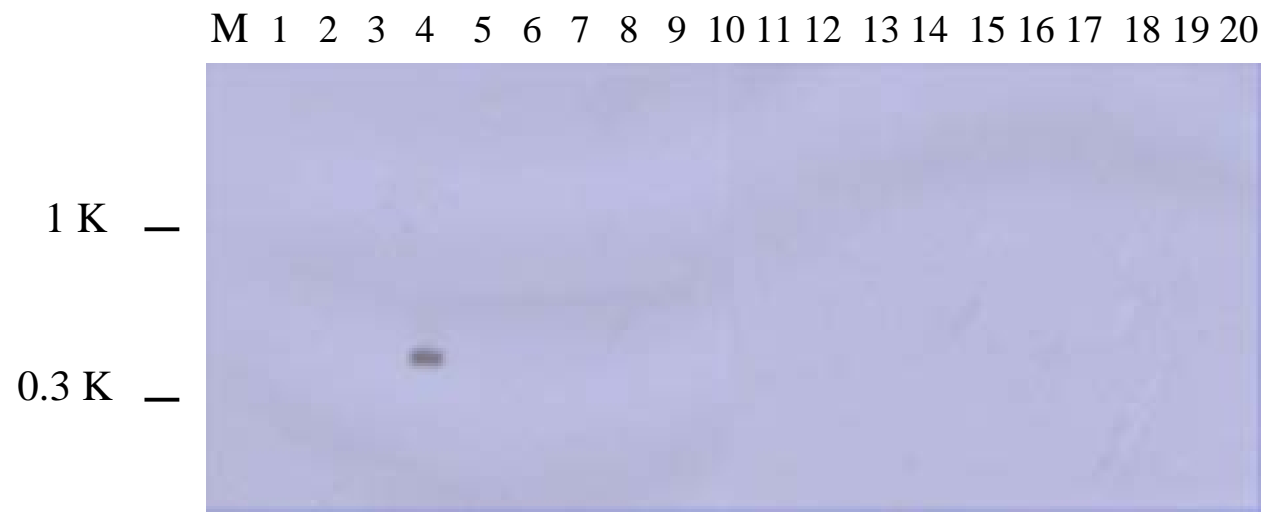

(b)

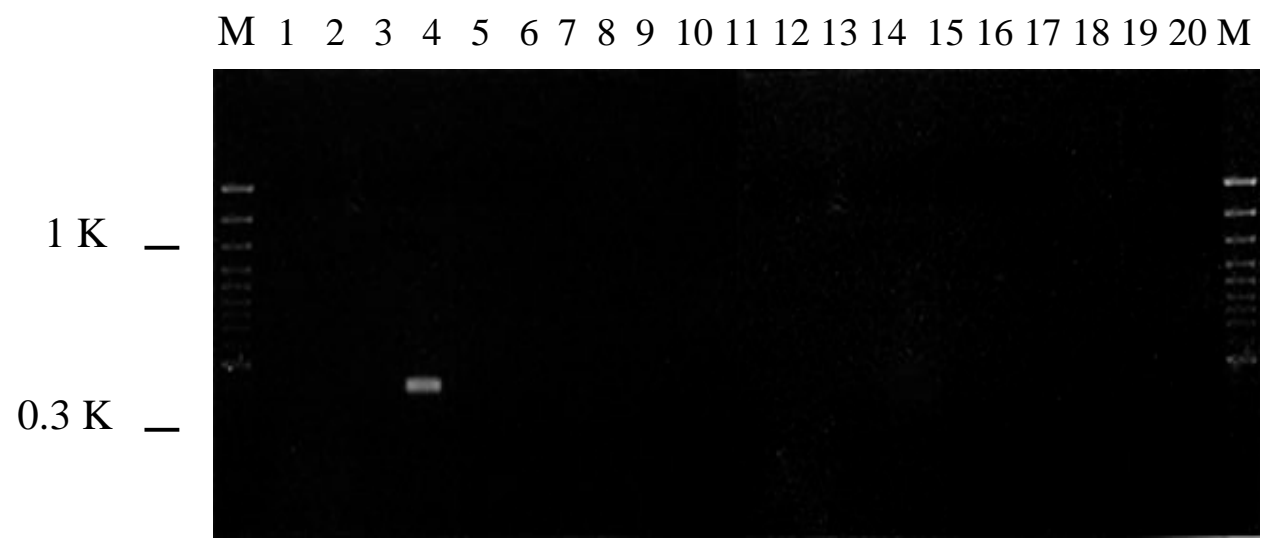

Fig. (2). PCR-based electrophoretic profiles and hybridization patterns. The Ficus species from left to right correspond to the same twenty species listed in Fig. (1) and lane M is the 100 bp DNA ladder marker. The numbers on the left of the figures indicate the DNA size markers in kilobases $(\mathrm{kb})$. (a) HAT-RAPD amplification from genomic DNA using the 10-mer primer OPX09. The HAT-RAPD marker OPX09 398 specific to $F$. hirta is indicated by an arrow. (b) Hybridization of the cloned and DIG-labelled HAT-RAPD fragment OPX09 ${ }_{398}$ (arrow) to a Southern blot of the HAT-RAPD gel. (c) SCAR amplification from genomic DNA using 20-mer sequence-specific primer pair OPX09F $1_{398} / \mathrm{OPX} 09 \mathrm{R} 1_{398}$. The unique amplification of a single SCAR marker in lane 4 for the species $F$. hirta shows that unique species can be characterized.

species fall into 3 broad morphological groups characterized as tree, shrub and the erect shrub form. As is shown in Fig. (3), the three species of Ficus of the "shrub" variety segregate as outgroups with the tree morphologies clustering together. The important fig species $F$. hirta chosen to be SCAR marker characterized is a member of the shrub family approximately 1-3 meter high with spirally arranged leaf of the ovate-oblong-lanceolate-obovate form. The erect shrub species $F$. microcrapa and $F$. benjamina Linn. present as 20 30 meter high erect-shrub morphologies which climb on other trees, and have thick branches with a spreading bush and large number of aerial roots arising from the stem.

Within the tree morphology group, the Fig species can be divided into four main subgroups according to morphology. These morphologies are indicated on Fig. (3) and show that 
Table 2. DNA Sequence of the HAT-RAPD Marker OPX09

\begin{tabular}{|c|c|c|c|c|c|c|}
\hline \multirow[t]{8}{*}{$5^{\prime}$} & $\frac{\text { GTGACCGAGT }}{\text { CACTG GCTCA }}$ & $\begin{array}{l}\text { GGAGCGCGTC } \\
\text { CCTCGCGCAG }\end{array}$ & $\begin{array}{l}\text { GAGACATCAT } \\
\text { CT CTGTAGTA }\end{array}$ & $\begin{array}{l}\text { TGTCAAGTCA } \\
\text { ACAGTTCAGT }\end{array}$ & $\begin{array}{l}\text { TTTACAATAG } \\
\text { AAATGTTATC }\end{array}$ & 50 \\
\hline & $\begin{array}{l}\text { TTAATGAATA } \\
\text { AATTACTTAT }\end{array}$ & $\begin{array}{l}\text { AA TCTCCCGC } \\
\text { TTAGAGGGCG }\end{array}$ & $\begin{array}{l}\text { CAGGCCTT TT } \\
\text { GTCCGGAAAA }\end{array}$ & $\begin{array}{l}\text { ATT GTGGCTT } \\
\text { TAACACCGAA }\end{array}$ & $\begin{array}{l}\text { CA AATAAGTA } \\
\text { GT T TAT TCAT }\end{array}$ & 100 \\
\hline & $\begin{array}{l}\text { CCCTGGAGGA } \\
\text { GGGACCTCCT }\end{array}$ & $\begin{array}{l}\text { TACGAGCTGT } \\
\text { ATGCTCGACA }\end{array}$ & $\begin{array}{l}\text { AAGATGCCAG } \\
\text { T TCTACGGTC }\end{array}$ & $\begin{array}{l}\text { GTCGACGATG } \\
\text { CAGCTGCTAC }\end{array}$ & $\begin{array}{l}\text { TACAAC TTGT } \\
\text { ATGTTGAACA }\end{array}$ & 150 \\
\hline & $\begin{array}{l}\text { CAGCTGCTAC } \\
\text { GTCGACGATG }\end{array}$ & $\begin{array}{l}\text { CCCTGGAGGA } \\
\text { GGGACCTCCT }\end{array}$ & $\begin{array}{l}\text { ATGTTGAACA } \\
\text { TACAACT TGT }\end{array}$ & $\begin{array}{l}\text { TACAACTTGT } \\
\text { ATGTTGAACA }\end{array}$ & $\begin{array}{l}\text { GTCCGGAAAA } \\
\text { CAGGCCTT TT }\end{array}$ & 200 \\
\hline & $\begin{array}{l}\text { TAATCGGCTA } \\
\text { ATTAGCCGAT }\end{array}$ & $\begin{array}{l}\text { TACAACTTGT } \\
\text { ATGTTGAACA }\end{array}$ & $\begin{array}{l}\text { TACAAAGCTG } \\
\text { ATGTTTCGAC }\end{array}$ & $\begin{array}{l}\text { TACGAGCTGT } \\
\text { ATGCTCGACA }\end{array}$ & $\begin{array}{l}\text { CCCGACCGCG } \\
\text { GGGCTGGCGC }\end{array}$ & 250 \\
\hline & $\begin{array}{l}\text { AAGATGCCAG } \\
\text { T TCTACGGTC }\end{array}$ & $\begin{array}{l}\text { CCCTGGAGGA } \\
\text { GGGACCTCCT }\end{array}$ & $\begin{array}{l}\text { GTCGACGATG } \\
\text { CAGC TGCTAC }\end{array}$ & $\begin{array}{l}\text { CCCCAACACT } \\
\text { GGGGTTGTGA }\end{array}$ & $\begin{array}{l}\text { AT TGCCCCAT } \\
\text { TAACGGGGTA }\end{array}$ & 300 \\
\hline & $\begin{array}{l}\text { GTGCGGAAGC } \\
\text { CACGCC TTCG }\end{array}$ & $\begin{array}{l}\text { CGCACCC TGT } \\
\text { GCGTGGGACA }\end{array}$ & $\begin{array}{l}\text { TGGCCACCAA } \\
\text { ACCGGTGGTT }\end{array}$ & $\begin{array}{l}\text { CAAGGGGAAT } \\
\text { GTTCC CCT TA }\end{array}$ & $\begin{array}{l}\text { GCCGTCTGCA } \\
\text { CGGCAGACGT }\end{array}$ & 350 \\
\hline & $\begin{array}{l}\text { CCC GTCGTGC } \\
\text { GGGCAGCACG }\end{array}$ & $\begin{array}{l}\text { GAGACGTCCG } \\
\text { CTCTGCAGGC }\end{array}$ & $\begin{array}{r}\text { TGTCCTCGAT } \\
\text { ACAGGACGTA }\end{array}$ & $\begin{array}{l}\text { GAACTCGGAC } \\
\text { CT TGAGCCTG }\end{array}$ & $\begin{array}{l}\text { TCG GTCAC } \\
\text { AGCCAGTG } \\
\end{array}$ & 398 \\
\hline
\end{tabular}

Underlined segments show the annealing position of the arbitrary primer (OPX09). Arrows indicate the position of primers for amplifying the sequence-characterized amplified region (SCAR) markers.

Table 3. Sequence-Specific SCAR Primers Derived from the Cloned HAT-RAPD Fragment of $F$. hirta

\begin{tabular}{|c|c|c|}
\hline SCAR Primer $^{\mathbf{a}}$ & $\mathbf{5}^{\prime}$ 'o 3' Sequence $^{\mathbf{b}}$ & ${\text { Annealing Temperature }\left({ }^{\circ} \mathbf{C}\right)^{\mathbf{c}}}^{{ }^{\mathbf{c}}}$ \\
\hline \hline${\text { OPW09 } \mathrm{F} 1_{398}}$ & GTG ACC GAG T GG AGC GCG T & 72 \\
\hline OPW09 $\mathrm{R}_{398}$ & GTG ACC GAG T CC GAG TTC A & 72 \\
\hline
\end{tabular}

${ }^{a}$ The letters and numbers preceding the $\mathrm{F}$ (Forward) and R Reverse) refer to the progenitor primer used (Op : Operon Technologies). The subscript indicates the size of the marker in bp. ${ }^{b}$ SCAR primers of 19 nucleotides were designed. The underlined sequences represent the original sequence of the progenitor RAPD primer.

'Optimal annealing temperature.

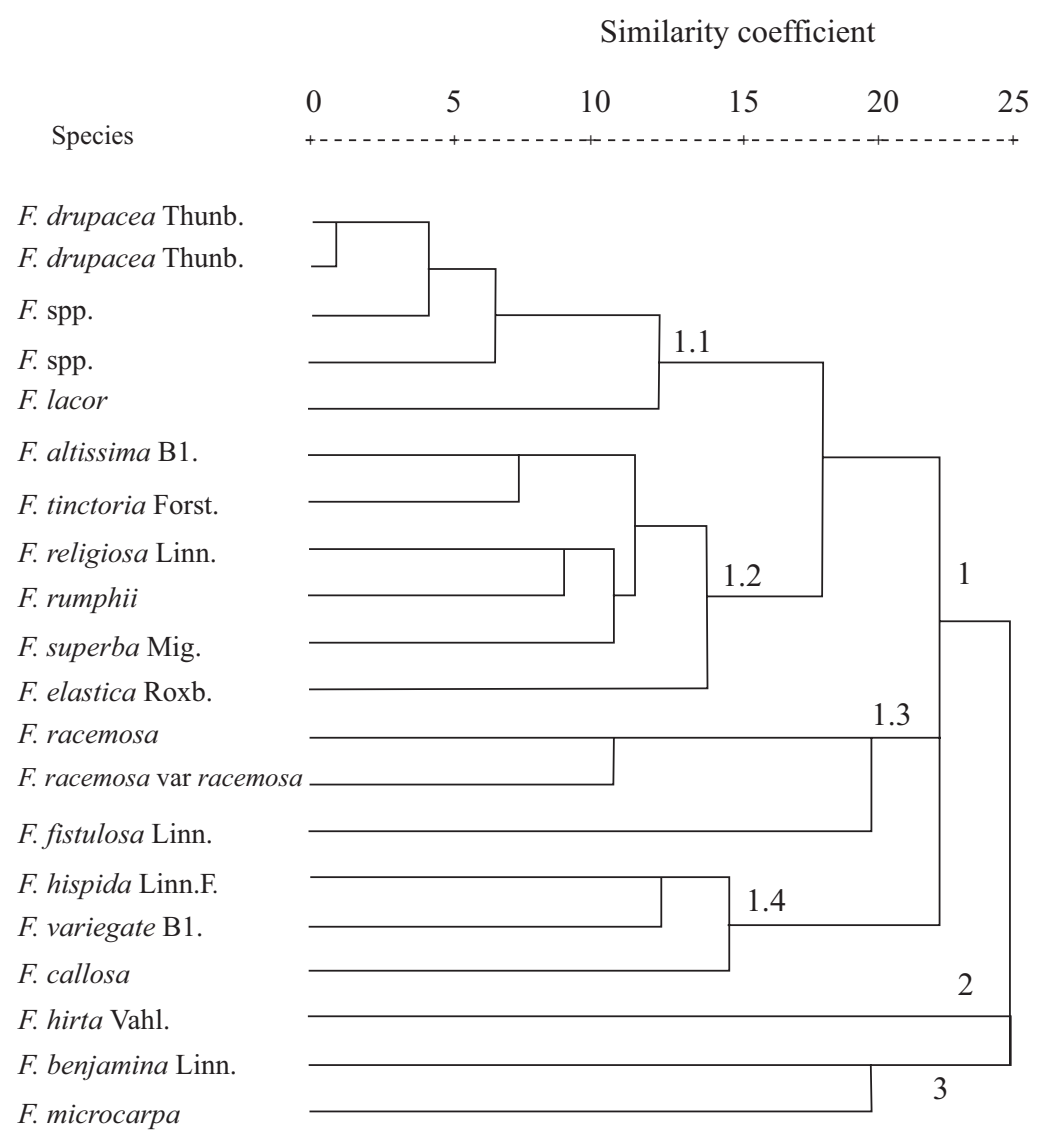

Fig. (3). Dendrogram illustrating genetic relationships among 20 Ficus spp. Generated using UPGMA cluster analysis from 172 HATRAPD markers. Group 1 consists of a variety of distinct tree morphotypes, group 2 contains 1-3 meter high shrubs with spirally arranged leaves, and group 3 contains erect shrubs 20-30 meters high which climb other trees and have thick branches with a spreading bush and large number of aerial roots arising from the stem. 
the molecular marker characterization can nicely distinguish between the main Ficus morphotypes. Subgroup 1a consists of Ficus trees with a large trunk approximately 5-7 meters high which are epiphytic when young. Ficus trees in subgroup $1 \mathrm{~b}$ grow to be $10-15$ meters high with a distinctive heart shaped single leaf. Subgroup 1c contains trees 10-25 meters high with oblong-lanceolate-obovate leaves. Subgroup $1 \mathrm{~d}$ can present as either a tall shrub or a tree between 0.5-18 meters high with ovate or elongate-ovate leaves.

The eight decamer primers used in this study provide sufficient distinct banding information to generate a similarity dendogram which upholds the basic morphological classes presented above. More importantly this banding information can be obtained inexpensively and rapidly using basic gel electrophoresis. To further characterize these Ficus species using SCAR primers, the SCAR marker methodology provides a phenotypically independent molecular based character upon which to classify and detect distinct varieties of Ficus. As a proof of principle for developing a genomic characterization for the complete set of fig species, the SCAR marker described above shows that the Ficus hirta species can be clearly distinguished using molecular markers, and that the broad range of generated bands provide ample source sequences to generate additional species or clade specific SCAR markers.

\section{ACKNOWLEDGEMENTS}

This research was conducted using funding from the following sources: The National Research Council of Thailand, the Thailand Research Fund, and Mark Halsey the Dean of the Science Division of Bard College.

\section{REFERENCES}

[1] Zohary D, Hopf M. Domestication of plants in the old world. Oxford: Clarendon Press; 1988.

[2] Bamikole MA, Ikhatua UJ, Babayemi OJ, Arigbede OM, Etela I, Osagie P. Assessment of forage acceptability, some nutritive and anti-nutritive components of Ficus species in Benin, Nigeria. In: Malau-Aduli, Adeyinka IA, Eds. Strategies for poverty alleviation: animal production option. Proceedings of the $26^{\text {th }}$ Conference of the Nigerian Society for Animal Production (NSAP). Zaria, Nigeria, 2001; pp. 310-3.

[3] Satyavati GV, Prasad DN, Gupta B, Srivastava RK. Studies on ulcerogenic activity of curcumin. Indian J Physiol Pharmacol 1976; 20(2): 92-3.

[4] Subramanian SS, Nair AGR. Sterols and flavonols of Ficus bengalensis. Phytochemistry 1970; 9(12): 2583-4.

[5] Johns SR, Russel JH, Helerman ML. Ficine, a novel flavonoidal alkaloid from Ficus pantoniana. Tetrahedron Lett 1965; 6(24): 1987-91.
[6] Manandhar NP. Native phytotherapy among the Raute tribe of Dadeldhura district, Nepal. J Ethnopharmacol 1998; 60: 199-206.

[7] Hedfi J, Trifi M, Hannachi-Salhi A, Ould Mohamed Salem A, Rhouma A, Marrakchi M. Morphological and izozymic polymorphisms in Tunisian fig (Ficus carica L.) collection. Acta Hortic 2003; 605: 319-25.

[8] Galderisi U, Cipollaro M, Di Bernardo G, De Masi L, Galano G, Cascino A. Identification of the edible fig 'Bianco del Cilento' by random amplified polymorphic DNA analysis. HortScience 1999; 3: 1263-5.

[9] Papadopoulou K, Ehaliotis C, Tourna M, Kastanis P, Karydis I, Zervakis G. Genetic relatedness among dioecious Ficus carica L. cultivars by random amplified polymorphic DNA analysis, and evaluation of agronomic and morphological characters. Genetica 2002; 114: 183-94.

[10] De Masi L, Cipollaro M, Di Bernardo G, et al. Clonal selection and molecular characterization by RAPD analysis of the fig (Ficus carica L.) "Dottato" and "Blanco del Cilento" cultivars in Italy. Acta Hortic 2003; 605: 65-8.

[11] Khadari B, Hochu I, Bouzid L, Santoni S, Roger JP, Kjellberg F. The use of microsatellite markers for identification and genetic diversity evaluation of the fig collection in CBNMP. Acta Hortic 2003; 605: 77-86.

[12] Cabrita LF, Aksoy U, Hepaksoy S, Leitao JM. Suit ability of isozyme, RAPD and AFLP markers to assess genetic differences and relatedness among fig (Ficus carica L.) clones. Sci Hortic 2001; 87: 261-73.

[13] Landry BS, Michelmore RW. Methods and applications of restriction fragment length polymorphism analysis to plant. In: Kosige $\mathrm{T}$, Hollaender A, Eds. Tailoring genes for crop improvement. Plenum Publishing Corp., New York, 1987; pp. 25-44.

[14] Paran I, Michelmore RW. Development of reliable PCR-based markers linked to downy mildew resistance genes in lettuce. Theor Appl Genet 1993; 85: 985-93.

[15] Cutler RW, Chundet R, Handa T, Anuntalabhochai S. Development of sequence characterized DNA markers linked to a temperature dependence for flower induction in lychee (Litchi chinensis Sonn.) cultivars. Sci Hortic 2006; 107: 264-70.

[16] Cutler RW, Sitthiphrom S, Marha J, Anuntalabhochai S. Development of sequence characterized DNA markers linked to a temperature insensitivity for fruit production in Longan (Dimocarpus longan Lour.) cultivars. Agr Crop Sci 2007; 193: 74-8.

[17] Anuntalabhochai S, Sitthiphrom S, Thongtaksin W, Sanguansermsri M, Cutler RW. Hybrid detection and characterization of Curcuma spp. using sequence characterized DNA markers. Sci Hortic 2007; 111: 389-93.

[18] Gu WK, Weeden NF, Yu J, Wallace DH. Large-scale, costeffective screening of PCR products in marker-assisted selection applications. Theor Appl Genet 1995; 91: 465-70.

[19] Weising K, Kaemmer D, Weigand F, Epplen JT, Kahl G. Oligonucleotide fingerprinting reveals various probe-dependent levels of informativeness in chickpea (Cicer arietinum). Genome 1991; 35: 436-42.

[20] Anuntalabhochai S, Chandej R, Chiangda J, Apavatjrut P. Genetic diversity within lychee Litchi chinensis Sonn. based on RAPD analysis. Acta Hortic 2000; 575: 253-9. 